\title{
THE IMPACT OF A SALARY LEVEL AND THE LEGAL MECHANISM FOR ITS REGULATION ON THE WORK EFFICIENCY OF HEALTH CARE WORKERS
}

DOI: $10.36740 /$ WLek202012220

\author{
Denys 0. Novikov, Oleh M. Lukianchykov, Vasyl 0. Mykytyuk \\ FACULTY OF LAW, DEPARTMENT OF CIVIL LAW DISCIPLINES AND LABOUR LAW NAMED AFTER PROF. O.I. PROTSEVSKIY, H.S. SKOVORODA KHARKIV \\ NATIONAL PEDAGOGICAL UNIVERSITY, KHARKIV, UKRAINE
}

\begin{abstract}
The aim: To determine the impact of the salary level and the legal mechanism for its regulation on the work efficiency of health care workers.

Materials and methods: The research materials cover the reports of international organizations, global and national statistical data and collective agreements. The research results and conclusions are based on the combined use of theoretical and empirical methods.

Conclusions: The legal mechanism for regulating the remuneration of health care workers should be reformed on the basis of the concept of their work efficiency.
\end{abstract}

KEY WORDS: health care workers, salaries, work efficiency, legal mechanisms, labor law, medical law

Wiad Lek. 2020;73(12 p. II):2821-2826

\section{INTRODUCTION}

The health care sector is an extremely important social sphere, whose level of development can be used to draw the conclusions about the level of the development of the whole country and to create effective mechanisms (including legal ones) for satisfying the needs of the people in decent medical services. We believe that health care professionals are at the heart of the entire health care sector, whose task is to provide qualified medical care and support patients in a state of illness, which includes, in particular, psychological assistance and regular human support.

Health care workers, while providing qualified medical care as medical professionals and, at the same time, supporting patients in their health assistance as socioeconomic professionals, experience several risks associated with the continuing influence of negative factors in the professional environment. Systematic stress has a negative impact on the health of medical professionals themselves. This is confirmed, for example, by the significant role of health care workers during the COVID-19 pandemic, when they were in the front line of fire to combat the dangerous virus and got infected themselves. The vulnerability of health care workers is linked to the functioning of appropriate legal and institutional mechanisms that minimize and compensate for the impact of these risks and provide appropriate incentives for them to remain in health care sector and provide effective services.

One such mechanism in the field of health care is to use the remuneration systems that can attract and retain the best professionals in the field, encourage them to perform their duties effectively, which combines the quality and intensity of health care workers with the understanding of the need for continuous self-education. Some issues relating to medical remuneration have been considered by A. Eltorai, C. Fuentes, W. Durand [1], S. Fayer, A. Watson [2], S. Hayes, J. Noseworthy, G. Farrugia [3], M. Menacker [4], J. Bisco, C. Cole, K. Bradley [5], D. Kumar, S. Sohal [6].

These researchers focused their attention on specific indicators in the field of healthcare, without taking into account the established legal remuneration mechanisms in the medical field. On the contrary, it is important to draw our attention to the interdependence of the salaries of health care workers and the legal mechanism for regulating remunerations in health care sector. First, we are talking about creating a legal mechanism that would ensure a decent level of remuneration for health care workers. This legal mechanism should, in our opinion, be calculated on the basis of the understanding of the importance of the social function of health care workers and achieving the highest possible level of efficiency in their work.

\section{THE AIM}

The purpose of our study is to determine the impact of the salary level and the legal mechanism for its regulation on the efficiency of health care workers.

\section{MATERIALS AND METHODS}

The study is based on the reports of the International Organization for Migration, the International Trade Union 


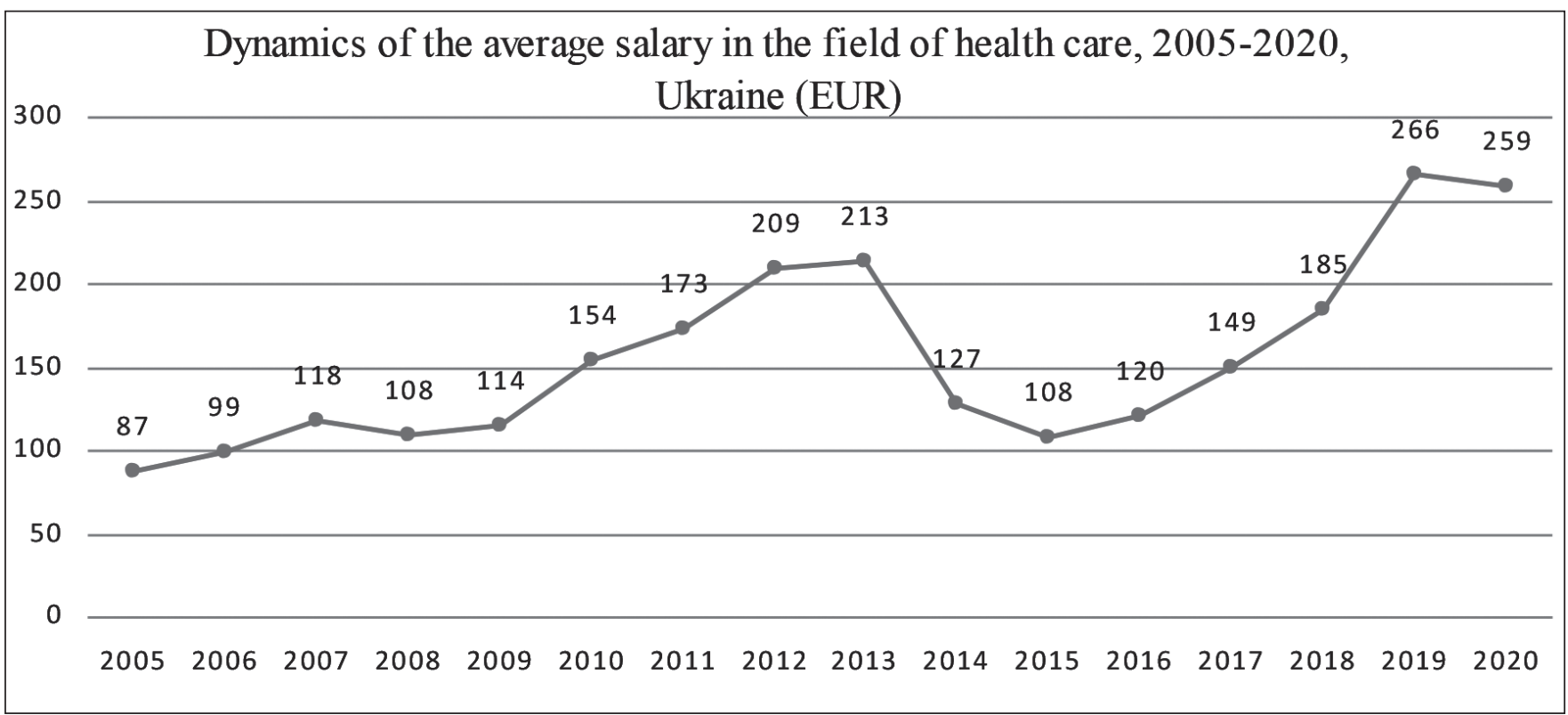

Fig. 1. The ratio of the average salary in the state and the average salary in the field of health care and social work activities, 2005-2020, Ukraine (EUR). Source: Data from State service of the statistics of Ukraine

Table 1. Number of health care workers in Ukraine and regions. Source: Data from State service of the statistics of Ukraine

\begin{tabular}{ccccccccc}
\hline & \multicolumn{4}{c}{ Number of Health care workers (Ukraine, regions) } \\
\cline { 2 - 10 } & \multicolumn{4}{c}{ total, thousand } & per 10 000 persons & \multicolumn{5}{c}{ total, thousand } & per 10 000 persons \\
\cline { 2 - 10 } & $\mathbf{2 0 0 5}$ & $\mathbf{2 0 1 9}$ & $\mathbf{2 0 0 5}$ & $\mathbf{2 0 1 9}$ & $\mathbf{2 0 0 5}$ & $\mathbf{2 0 1 9}$ & $\mathbf{2 0 0 5}$ & $\mathbf{2 0 1 9}$ \\
\hline Ukraine & 224 & 187,9 & 47,9 & 45,04 & 496 & 331,8 & 106,2 & 79,51 \\
\hline Kharkiv Region & 15,8 & 13,8 & 56,1 & 52,53 & 28,7 & 20,8 & 102,0 & 79,0 \\
\hline Vinnytsia Region & 8,3 & 7,7 & 48,9 & 50,2 & 18,9 & 13,0 & 111,7 & 84,85 \\
\hline Zakarpattia & 5,2 & 4,4 & 42,1 & 35,4 & 12,9 & 8,8 & 104,1 & 70,55 \\
\hline
\end{tabular}

Confederation, statistics collected by Eurostat, the Ministry of Health of Ukraine, the State Service of Statistics of Ukraine and its regional branches, the State Statistical Service of the Republic of Poland. The study material included regulations, jurisprudence of national courts of Ukraine, collective agreements of Kharkiv hospitals.

The statistical indicators used in the study reflect the data between 2005 and 2020. The relationship between the level of salaries and the legal mechanism of their regulation to the effectiveness of health care workers was examined on the basis of indicators of salary dynamics and the amount of the service and standardization of work established by the regulatory acts.

The research results and conclusions are based on the combined application of theoretical and empirical methods. Among the theoretical methods, the comparative, normative-logical and prognostic methods have been used. The empirical methods have been used in the study for processing the statistics, comparing and summarizing.

\section{REVIEW AND DISCUSSION}

The study of the level of health care workers remuneration covers the period from 2005 to 2020 . We found out that the dynamics of the salaries of health care workers for the selected period has positive growth indicators (except for the period from 2014 to 2018). In relation to the average salary in the state, the salaries of health care workers traditionally remain lower, despite the medical reform.

According to the State Statistics Service of Ukraine, since the second quarter of 2020, the average monthly salary of full-time health care workers has been 7,720 UAH (259€), which is 70.7\% of the average salary in the country - 10,928 UAH (366€). In terms of the average monthly salary, this area has the $23 \mathrm{rd}$ rank out of 26 [7].

As we can see, the efficiency of health care workers depends not only on the amount of the salary, but also on the work load of such an employee and on the interdependence and the ratio of the salary to the work load. That's why we are turning to the study of the dynamics of the work load, which is best demonstrated by the dynamics of changes in the number of health care workers.

According to the reference book "Medical Personnel and the Network of Health care Institutions of the Ministry of Health of Ukraine for 2018-2019", prepared by the workers of the State Institution "Center for Medical Statistics of the Ministry of Health of Ukraine" in 2019, there are 18,797,275 full-time medical positions in Ukraine 16,328,175 - occupied medical positions, and the number of individual physicians is 154,265 


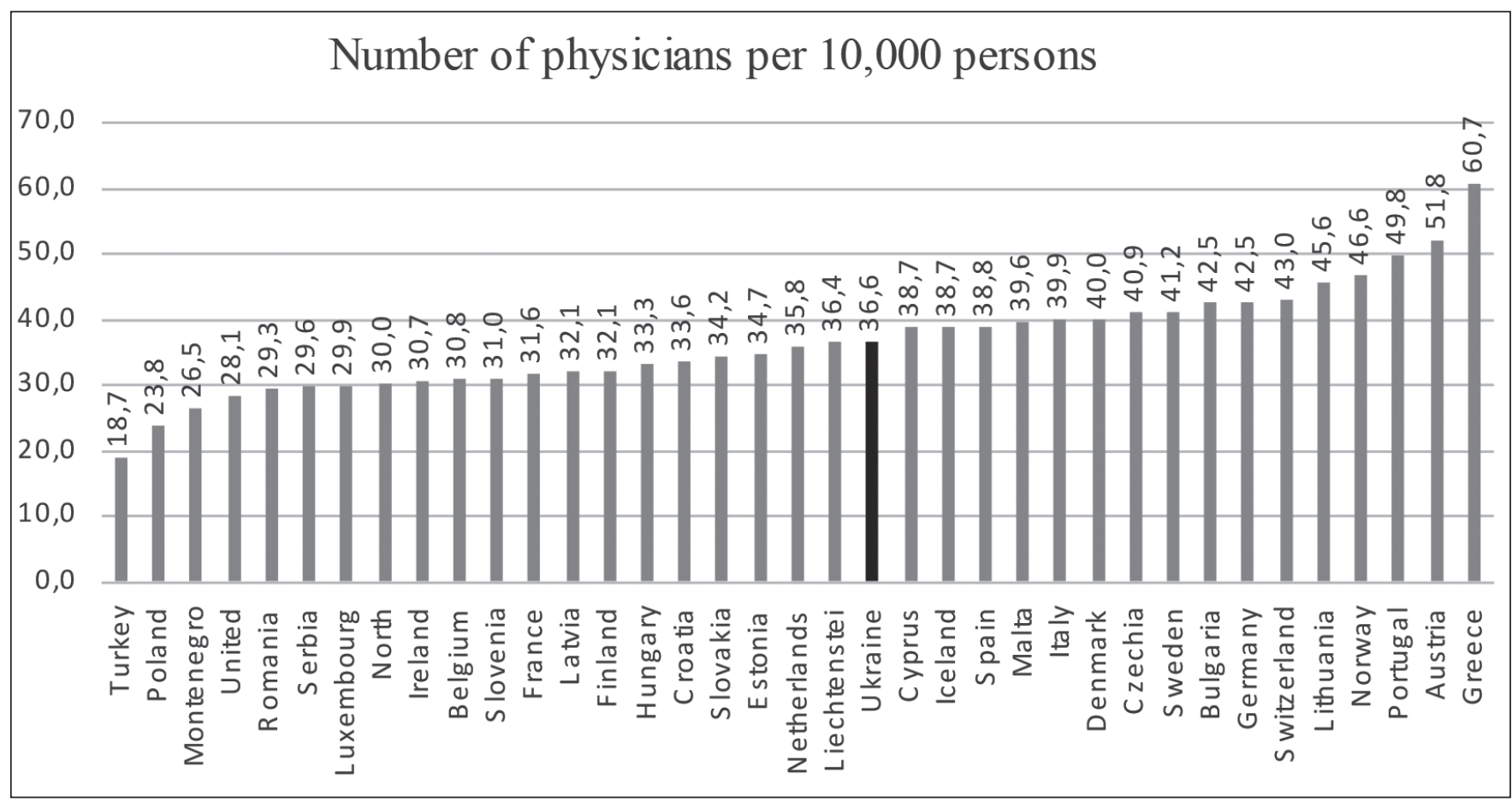

Fig. 2. Number of physicians per 10,000 persons. Source: Data from Eurostat

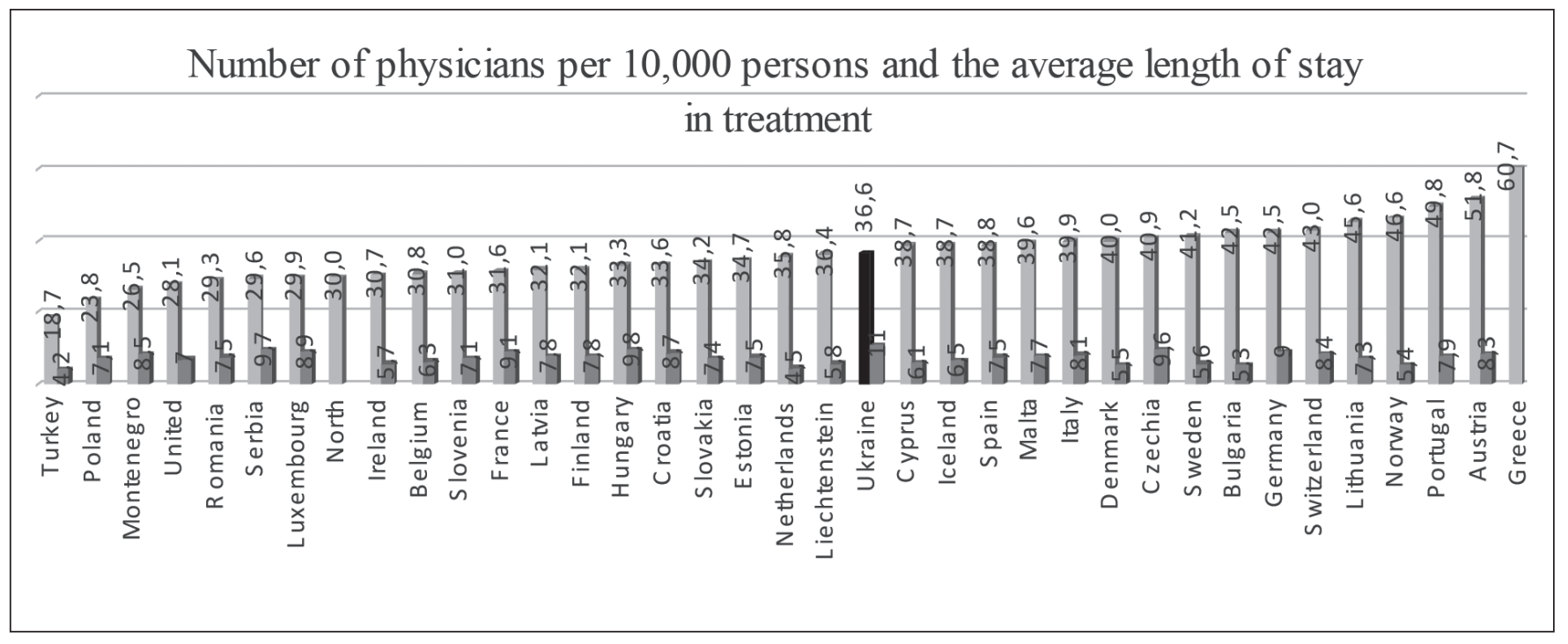

Fig. 3. Number of physicians per 10,000 persons and the average length of stay in treatment. Source: Data from Eurostat.

[8]. For the correct analysis, we should point out that the above indicators (Table 1) show the number of full-time medical positions, but not the number of doctors.

Our figures show that during the selected period there was a reduction in the number of physicians and the nursing staff in both absolute and relative numbers. The relative number of physicians (per 10,000 persons) in Ukraine decreased by $5.97 \%$ and the number of the nursing staff - by $25.13 \%$. There was a $25.13 \%$ increase in the workload of the nursing staff, which may lead to an increase in the workload of doctors, who, with a shortage of the necessary number of nurses, will have to perform their duties as well. The dynamics of changes in the number of physicians is uneven through the regions: a decrease in Kharkiv Region - by 6.36\%, in Zakarpattia - by
$15.91 \%$, but in Vinnytsia there is an increase of $2.66 \%$. The dynamics of changes in the number of average medical staff is less polarized. The attention should also be paid to the difference in the dynamics of reduction in the relative number of physicians (5.97\%) and the nursing staff (25.13\%). At the same time, according to the Eurostat report, the number of physicians per 10,000 inhabitants in the European Union varies between 18.6 (in Turkey) and 60.6 (in Greece), with an average of 36.4. Between 2012 and 2017, the number of physicians increased in all EU countries (9).

At the same time, we can observe the following situation in Ukraine: the amount of work, calculated for 187,972 full-time health care workers, is actually performed by 154,265 health care workers. The real availability of physicians in Ukraine is 


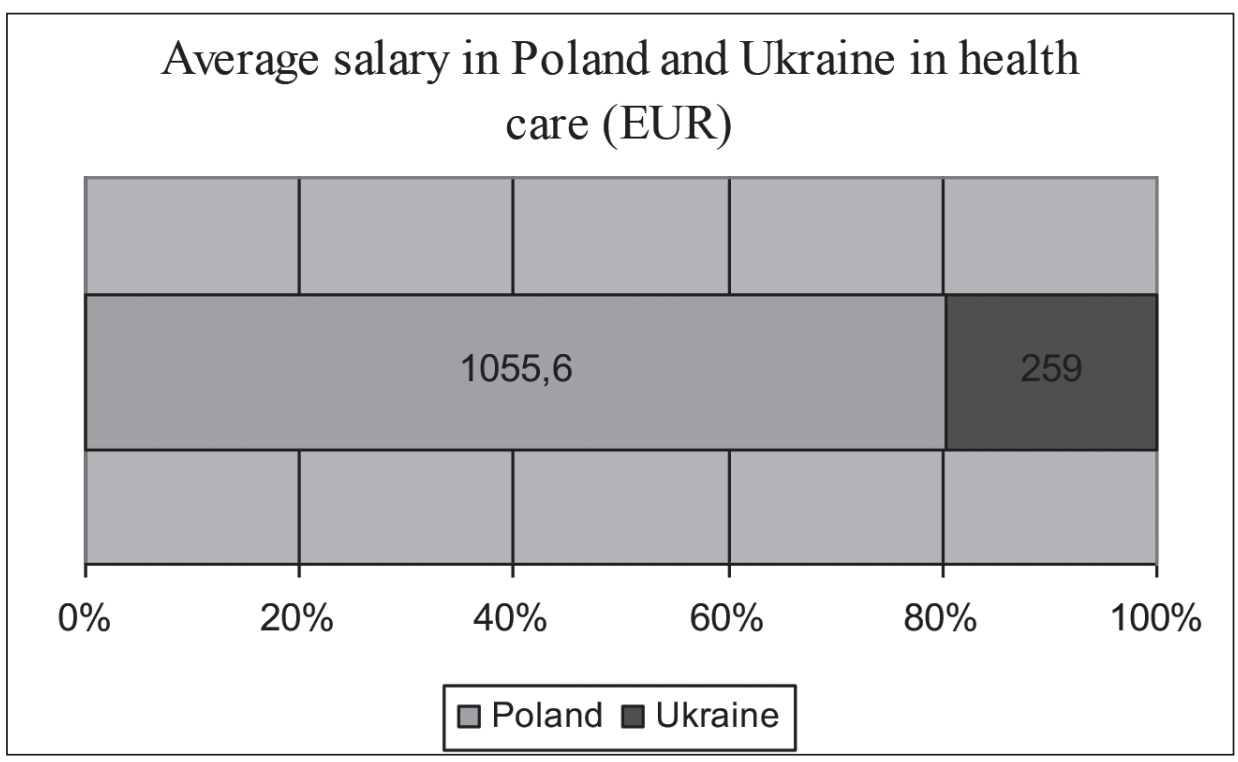

Fig. 4. Average salary in Poland and Ukraine in health care (EUR). Source: Data from Rocznik Statystyczny Pracy and State service of the statistics of Ukraine

36.96 per 10,000 persons and there are 270 patients per a physician (222 patients per a doctor are planned for the number of full-time positions). Thus, the physician's workload is $21.6 \%$ more than planned. According to the regional indicators (Table 1), the workload of physicians in Kharkiv Region is $48.3 \%$ higher than in Zakarpattia (in 2005 that difference was 33.2\%). At the same time, the average monthly salary in the field of health care in Kharkiv Region as of June 2020 is only $12.7 \%$ higher [10].

We believe that the imperfect regulation of the remuneration of health care workers poses a significant risk of their migration to the European Union, particularly to Poland.

If to compare the dynamics of migration from Ukraine we can see that in the peak years of the reduction in the number of healthcare workers, there were the highest rates of migration. According to the report of the International Organization for Migration, from 2008 to 2018 the number of first issued residence permits for Ukrainian citizens in the EU countries increased almost 5 times [11]. During this period Poland became the main destination country for the labor migrants from Ukraine (their number increased five times) [11]. One of the industries that attracted Ukrainian citizens was the health care sector. In 2018, the average salary in the health care sector in Poland was $1,015.2 \mathrm{EUR}$, which is $96.2 \%$ of the average salary in the country - 1,055.6 EUR. In terms of the average monthly salary, this sector ranks 10 out of 18 [12].

The number of physicians per 10, 000 inhabitants is 23.7 in Poland and 36.96 in Ukraine respectively. The doctor's workload in Poland is 55\% higher than in Ukraine, and the salary is $425 \%$ higher. The number of physicians in Poland is increasing [9], the workload of physicians is decreasing, while in Ukraine the opposite trend is observed. At the same time, in 2019, the deficit of medical staff in established positions of doctors was $12 \%$ and the deficit of nurses was 7\% [13].

In order to understand the prerequisites of the considered negative trends in the remuneration of health care workers, we will turn to the analysis of the current system of the remuneration of health care workers in Ukraine. It should be noted that the current system of payment for health care workers was formed in 2005. Since then, the payment for health care workers has been regulated by the Order of the Ministry of Labor and Social Policy of Ukraine, the Ministry of Health of Ukraine № $308 / 519$, which approved the "The terms of the regulation of labor remuneration of health care facilities and institutions of social protection".

The remuneration system does not provide an automatic increase in the physician's salary in connection with the increase in the number of patients. Instead of that, it provides some additional payments for the expansion of the service area or an increase in the scope of work, which is up to 50 per cent of an employee's official salary. These extra payments are set for the workers if they are working with a smaller number of workers than the established standards require. The state does not establish the criteria for the dependency of the extra payments on the expansion of the scope of services.

In our opinion, in this aspect the system of calculating salaries of workers did not meet the requirements of the Law "On Remuneration of Labor" for years and was much smaller. This fact was recognized by the state only in 2016, when the current approach to calculating salaries was declared to be illegal. That is why it cannot be considered that such a surcharge really compensated for the increase in the workload $[14 ; 15]$. In the current tariff system of remuneration of health care workers, the salaries (tariff rates) from January 1, 2017 are calculated based on the salary (tariff rate) of the employee of the 1st tariff category, set at the subsistencelevel for able-bodied persons on January, 1 of the calendar year. However, it cannot be considered to be fair, as the state itself recognizes that the subsistence level is not the subsistence level [16].

As a result of the medical reform in Ukraine, the system of remuneration of health care workers has not changed. Funds that can increase the salaries are transferred to hospitals. The legislator and the Ministry of Health of Ukraine have not established new criteria for calculating salaries in the framework of medical reform. In this situation, there are two parts of the 
salaries of health care workers, which are already included in the reform: one is mandatory, regulated by "The terms of the regulation of labor remuneration of health care facilities and institutions of social protection", and the second - variable (bonus) - regulated by a collective agreement, the regulation on bonuses and the order of the chief physician.

The specific amount of the premium is set monthly by the order of the chief medical officer of the health care institution "taking into account the personal contribution of the employee to the overall result of the work". The regulation of the remuneration by the order of the chief medical officer leads to the situation where the amount of the bonus has been set at $12 \%$, $15 \%$, and $25 \%$ of the amount of the funding of the declarations made with the doctor on the same basis positions in various hospitals. Then the situation is as follows: the basic salary is 2.5 times less than the "bonus". For example, a family doctor of the highest category has 14 tariff classes and the tariff coefficient 2.42 is used to calculate the salary. The tariff rate for such a doctor is 5,086 UAH (156 EUR) and the monthly bonus is 12,734 UAH (391 EUR). So, we can state that the variable part of the salary, which is regulated by the acts of the social dialogue and the order of the chief medical officer, is the main one. However, the powers of the chief medical officer to determine the amount of the bonus are limited by the possibility of influencing the staff of the health care institution on the size of the latter by concluding a collective agreement. However, according to the Global Index of Workers' Rights, compiled by the International Confederation of Trade Unions, due to the almost complete absence of independent unions, Ukraine has a rating of 5 (worst - 5+) [17]. Therefore, it is questionable whether to use social dialogue to effectively regulate the remuneration of health care workers in Ukraine.

On this basis, as part of the medical reform, there is a situation of unjustified differentiation of salaries at the expense of bonuses. Health care workers who are out of the reform receive a fixed salary that is linked to the labor standards, and a bonus is awarded only as an additional remuneration (optional). Health care workers in the reform area also receive a fixed basic salary, but in addition they receive a bonus (obligatory), the amount of which depends on the will of the chief medical officer but not on the work efficiency.

In our opinion, in order to improve the situation with the salaries in the health care sector in Ukraine, it is necessary to reform the medical sector based on the efficiency of work and create appropriate legal support. After all, in today's environment, if health care workers simply receive higher salaries than a competitive market, it will involve containing costs in this sector while maintaining the current quality level [18]. Health care workers often report that low salaries are a barrier to efficiency, but there is little evidence that the higher salaries actually bring better results. Therefore, the benefit of the efficiency-based salary is that it aligns the bonuses and remuneration of health care workers with the specific goals of the district or the facility, where the health care workers employed. This motivates health workers to pursue their goals in order to receive additional compensation for achieving the goals.

We must emphasize that it is important to differentiate between the salaries based on the concept of efficiency and effectiveness, i.e. based on concluding contracts with a certain number of potential patients (in Ukraine - declarations) and cured patients. In the latter case, the heads of health care institutions usually have a very high degree of freedom in recruiting workers and paying compensation (bonuses) for their results achieved. There are numerous potential gaps in performance-based remuneration: the risk of unnecessary care; the risk of increasing medical care costs; and bonuses based on the improved productivity or quality of care, regardless of who is receiving the help and who really needs it.

We believe that the main impulse for efficiency-oriented remuneration is to increase the efficiency of health care workers (e.g., work efficiency, service quality) in order to improve the quality of medical care and, finally, the health status of citizens. For this purpose, it is necessary: 1) to transfer the right to hire health workers to non-governmental organizations on fixed-term contracts for a maximum of five years; 2) to give non-governmental organizations the right to monitor the salaries of health workers throughout the country and regions; 3 ) to establish a certain number of claims made to patients with territorially differentiated and resolute medical treatment; 4) to set the minimum salary of a health care employee at the level of the average salary in the country; 5) to combine individual (pay on the basis of the performance of the doctor in particular issue) and collective tools to stimulate effective work (premiums depending on the size of the services, labor intensity, etc.). Individual incentives are allowed by non-governmental organizations and collective incentives by health care providers.

This legal mechanism must be carefully designed. For example, their implementation in the practice of health care workers in Cambodia has shown that the incentives focused on labor productivity were too low to have a significant impact on health care workers' activities. In Romania, incentives to encourage doctors to work in rural areas did not work because they were too small and illegal. Poorly designed incentives can lead to socially undesirable results. In China, the bonuses aimed at improving doctors' efficiency have increased the provision of unnecessary services and medicines and in some cases reduced the productivity [19]. Therefore, when developing an approach based on the efficiency of health care professionals, it is necessary to examine carefully the potentially beneficial and harmful consequences.

\section{CONCLUSIONS}

Despite the ongoing medical reform, the salaries in the health care service in Ukraine remain among the lowest in the state economy. The current level of salaries does not allow an effective performance of medical assistance and does not create incentives for the recruitment, retention, development and quality performance of health care workers.

Formal increases in the salaries of health care workers are not the right strategy, as it involves an increase in the cost of health care without any guarantee of improvement. Pay rises are more effective in terms of productivity objectives.

The payment based on the achievement of efficiency objectives for health workers is linked to the development of a legal mechanism. This mechanism should include 
the granting of lease rights under fixed-term contracts to non-governmental organizations which will monitor the health care salaries; the setting of a minimum salary for health care workers should not be less than the national averages salary taking into account regional variations; and a combination of individual and collective incentives for the effective work of health care workers.

All elements of the recast mechanism for regulating the remuneration of health workers should be thoroughly examined and tested in separate regions.

\section{REFERENCES}

1. Eltorai A, Fuentes C, Durand W. Financial Implications of Physician Specialty Choice. Rhode Island Medical Journal. 2018; 10: 50-55.

2. Fayer S, Watson A. Employment and Wages In Health care Occupations. Bureau of Labor Statistics. 2015: 1-23. Available from: https://www. bls.gov/spotlight/2015/employment-and-wages-in-healthcareoccupations/pdf/employment-and-wages-in-healthcare-occupations. pdf [reviewed 2020.08.10].

3. Hayes S, Noseworthy J, Farrugia G. A Structured Compensation Plan Results in Equitable Physician Compensation: A Single-Center Analysis. Mayo Foundation for Medical Education and Research n Mayo Clin Proc. 2020; 95(1): 35-43.

4. Menacker M. Physician compensation methodology must change. Am J Med. 2019; 132 (5): 554-555.

5. Bisco J, Cole C, Bradley K. The Effect of Government-Run Health care on the Salaries of Nursing Professionals in the U.S. Journal of Insurance Issues. 2017; 2 (40): 215-246.

6. Kumar D, Sohal S. Overview of Health Care Expenditure \& Health care Payment Methods in India. Health Econ Outcome Res Open Access. 2018;4:1-6. Available from: https://www.iomcworld.org/open-access/ overview-of-health-care-expenditure--healthcare-payment-methodsin-india-2471-268X-1000154.pdf [reviewed 2020.08.10].

7. Ukrstat. Seredn'omisyachna zarobitna plata shtatnykh pratsivnykiv za vydamy ekonomichnoyi diyal'nosti za period z pochatku roku u 2020 rotsi [The average monthly salary of full-time workers by type of economic activity for the period from the beginning of the year in 2020];2020. Available from: http://www.ukrstat.gov.ua/operativ/ operativ2020/gdn/Zarp_ek_p/Zarp_ek_p2020_u.xlsx [reviewed 2020.08.13] (Ua).

8. Medstat; 2019. Available from: http://medstat.gov.ua/im/upload/ kadry\%202019.zip [reviewed 2020.08.13] (Ua).

9. Eurostat. Health care personnel statistics - physicians Statistics Explained. Available from: https://ec.europa.eu/eurostat/ statisticsexplained/ [reviewed 2020.08.13].

10. Ukrstat. Serednya nominal'nazarobitna plataza vydamy ekonomichnoyu diyal'nosti [Average nominal wages by type of economic activity]. Available from:http://www.uz.ukrstat.gov.ua/statinfo/dohodi/2020/ sered_mis_zar_econ_2020.pdf [reviewed 2020.08.16] (Ua).

11. IOM. Migration. Ukraine; 2019. Available from: https://iom.org.ua/sites/ default/files/iom-ukraine_facts-ukr_2019.pdf [reviewed 2020.08.10].

12. Statistics Poland. Rocznik Statystyczny Pracy [Yearbook of Labour Statistics]; 2019. Available from: https://stat.gov.pl/en/topics/ statistical-yearbooks/statistical-yearbooks/yearbook-of-labourstatistics-2019,10,7.html [reviewed 2020.08.16].

13. Bogdan D, Boyko A, Vakilkova A et. al. Kadrovi resursy systemy oxorony zdorov'ya v Ukrayini [Human resources of the health care system in Ukraine]. USAID Health Care Reform Support Project; 2019: 133. (Ua).
14. Postanova Okruzhnoho administratyvnoho sudu mista Kyeva [Resolution of the District Administrative Court of Kyiv] № 826/26538/15, 25.05.2016; 2016. Available from: https://zakon.rada.gov.ua/laws/ show/v2653805-16\#n50 [reviewed 2020.08.16] (Ua).

15. Postanova Kyyivs'koho apelyatsiynoho administratyvnoho sudu [Resolution of the Kyiv Administrative Court of Appeal] №826/26538/15, 08.09.2016; 2016. Available from: https://zakon.rada.gov.ua/rada/ show/v6538805-16\#n2 [reviewed 2020.08.16] (Ua).

16. Lukianchykov 0. Symulyakr bazovogo derzhavnogo social'nogo standartu. Aktual'ni problemy pryvatnogo ta publichnogo prava [Simulacrum of the basic state social standard. Current issues of private and public law]. Kharkiv. Current issues of private and public law: 2020: 167-170. (Ua).

17. MKTU. Hlobal'nyy indeks dotrymannya prav trudyashchykh [Global Index of Workers' Rights]. International Confederation of Trade Unions; 2020: 64. (Ua).

18. Glied S, Ma S, Pearlstein I. Understanding Pay Differentials among Health Professionals, Nonprofessionals, and Their Counterparts in Other Sectors. Health affair; 2015; 34; 6: 929-935. doi: 10.1377/ hlthaff.2014.1367.

19. Vujicic M. How You Pay Health Workers Matters: A Primer on Health Employee Remuneration Methods. Available from: https://www. rbfhealth.org/sites/rbf/files/RBF_Tech_howyoupayhealthworkers_ R1.pdf [reviewed 2020.08.16].

\section{ORCID and contributionship:}

Denys O. Novikov: 0000-0003-2727-5357 A, D

Oleh M. Lukianchykov: 0000-0003-3768-5608 B, C,

Vasyl O. Mykytyuk: 0000-0002-4744-7403 ${ }^{E, F}$

\section{Conflict of interest}

The Authors declare no conflict of interest.

\section{CORRESPONDING AUTHOR \\ Denys 0. Novikov}

Faculty of Law, Department of civil law disciplines and

labour law named after prof. 0.I. Protsevskiy, H.S. Skovoroda Kharkiv national pedagogical university

29 Alchevsky str., 61002, Kharkiv, Ukraine

tel: +380978200517

e-mail: d.novikov@hnpu.edu.ua

Received: 26.09 .2020

Accepted: 27.11.2020

A - Work concept and design, B - Data collection and analysis, C - Responsibility for statistical analysis,

$\mathbf{D}$-Writing the article, $\mathbf{E}-$ Critical review, $\mathbf{F}-$ Final approval of the article 